\title{
CHARACTERIZATION OF PROGNOSTIC FACTORS OF BREAST CANCER AMONG WOMEN WITH THIS CONDITION ATTENDED BY THE BRAZILIAN UNIFIED HEALTH SYSTEM IN THE MUNICIPALITY OF BAGÉ, RIO GRANDE DO SUL, BRAZIL
}

\author{
Caracterização dos fatores prognósticos do câncer de \\ mama em mulheres com essa condição atendidas pelo Sistema Único \\ de Saúde no município de Bagé, Rio Grande do Sul, Brasil
}

\author{
Hanan Jumah Eid Ahmah Laila* (D), Jenifer Rafaela Grzeczinski Zenkner² (D), \\ Maurício Collares Araújo³ (D), José Dionísio de Lima Becker ${ }^{3}$ (D), Adriana Dall'Asta Pereira'
}

\section{ABSTRACT}

Objective: This study aimed to characterize the prognostic factors of breast cancer among women with this pathology treated by the Brazilian Unified Health System in the Municipality of Bagé, Rio Grande do Sul, which comprises the municipalities of the $7^{\text {th }}$ Regional Health Coordination. Methods: This study was documentary, retrospective and quantitative in nature and based on the analysis of the medical records of patients undergoing cancer treatment who were attended at the oncological treatment unit in Bagé, from December 2010 to June 2017. Results: The results showed a total of 349 patients with breast cancer in the analyzed period, and their age ranged from 24 to 90 years, with the highest frequency presenting in white women in the left breast (42\%). Most of the cancers were smaller than $2 \mathrm{~cm}$ (53.9\%), with no lymph node involvement (57\%) and without distant metastases (93.4\%), and the majority of patients were diagnosed in the early stages, I (36.4\% \%) and II (32.4\%). Regarding the anatomopathological and immunohistochemical characteristics, invasive ductal carcinoma was the most common type (79.7\%), the histological grade II was present in more than half of cases (56.5\%), and $78.8 \%$ of the patients presented with the expression of hormone receptors, whereas $16 \%$ had HER2 overexpression; the luminal subtype B was present in $64.8 \%$ of the patients. Conclusion: Thus, it is noted that most patients are diagnosed in the early stages. Nonetheless, it is still necessary to adopt measures that guarantee diagnosis in pre-invasive phases.

KEYWORDS: breast neoplasms; immunohistochemistry; prognosis.

\section{RESUMO}

Objetivo: Este estudo objetivou caracterizar os fatores prognósticos do câncer de mama entre mulheres portadoras dessa patologia atendidas pelo Sistema Único de Saúde no município de Bagé, Rio Grande do Sul, o qual abrange os municípios da 7 a Coordenadoria Regional da Saúde. Método: Este estudo foi do tipo documental, retrospectivo e quantitativo a partir da análise dos prontuários médicos das pacientes em tratamento de câncer atendidas na unidade de tratamento oncológico em Bagé, de dezembro de 2010 a junho de 2017. Resultados: Os resultados demonstraram um total de 349 pacientes com câncer de mama no

${ }^{1}$ Universidade Franciscana (UFN) - Santa Maria (RS), Brazil.

Instituto de Educação e Pesquisa, Hospital Moinhos de Vento - Porto Alegre (RS), Brazil.

${ }^{3}$ Clínica Oncológica Bagé - Bagé (RS), Brazil.

*Corresponding author: hananlaila_87@hotmail.com

Conflict of interests: nothing to declare.

Received: 11/05/2018. Accepted: 12/27/2018 
período analisado; a faixa etária variou dos 24 aos 90 anos, sendo a maior frequência em mulheres brancas, na mama esquerda (42\%). A maior parte dos carcinomas possuía tamanho inferior a $2 \mathrm{~cm}$ (53,9\%), sem comprometimento linfonodal (57\%) e sem metástases a distância (93,4\%), e as pacientes são diagnosticadas particularmente em estádios iniciais - I (36,4\%) e II (32,4\%). Com relação às características anatomopatológicas e imuno-histoquímicas, o carcinoma ductal infiltrante foi o tipo mais presente (79,7\%), e o grau histológico Gll esteve presente em mais da metade dos casos (56,5\%). Quanto à expressão dos receptores hormonais, $84,7 \%$ das pacientes a apresentavam, e 12,5\% possuíam superexpressão do fator de crescimento humano epidérmico receptor-2 (HER2); o subtipo Luminal B esteve presente em 64,8\% das pacientes. Conclusão: Dessa forma, verificamos que a maior parte das pacientes é diagnosticada em estádios iniciais. Entretanto, ainda é necessária a adoção de medidas que garantam o diagnóstico em fases pré-invasivas.

PALAVRAS-CHAVE: neoplasias de mama; imuno-histoquímica; prognóstico.

\section{INTRODUCTION}

Breast tumors are complex and multifactorial malignancies caused by genetic mutations, especially the genes involved in the regulation of cell growth. For this reason, most cases of breast cancer are said to be sporadic, due to changes in genes acquired throughout life. However, a small part, approximately $10 \%$, is associated with the hereditary factor'.

Other risk factors also interfere with the genesis of breast cancer, such as alcohol consumption, high breast density, obesity, radiation exposure and race. Endocrine or reproductive-related factors also influence the history of early menarche, late menopause, nulliparity and pregnancy after 30 years of age. In addition, advanced age remains one of the most important risk factors, since the incidence increases rapidly until the age of 50, reinforcing the participation of female hormones in the etiology of the disease. However, when it affects young women, breast cancer is more aggressive, with high mutation rates in BRCA-1 and BRCA-2 genes and overexpression of human epidermal growth factor receptor-2 (HER2), demonstrating clinical and epidemiologies quite different from those observed in older women ${ }^{2}$.

In Brazil, estimates from the National Cancer Institute (INCA) show that there will be more than 59,700 new cases per year of this cancer, particularly among the female population with high mortality rates that are increasing which is probably linked to the delays in diagnosis, especially in stages III and IV 2 .

When patients are diagnosed with breast cancer, it is necessary to evaluate the prognostic factors, such as: age of diagnosis, tumor size, axillary lymph node involvement, staging, type and histological stage (HS), molecular markers (p53 gene, HER2, and others) and immunohistochemical markers - IHC markers (estrogen hormone receptor (ER) and progesterone hormone receptor (PR) and Ki-67 antigen expression). Prognostic factors used in clinical oncology practice serve to help in the selection of specific individualized therapies and to predict the risk of tumor recurrence and metastasis ${ }^{3}$.

In view of the above, the study is justified as the high incidence and mortality of breast cancer represent a serious public health problem. Being aware of the clinical and pathological aspects of breast cancer is of extreme importance not only to propose preventive measures, but also to determine more specific, effective and individualized therapeutic programs for each patient.

Therefore, this study aimed to characterize the prognostic factors of breast cancer among women carriers of this pathology treated by the Unified Health System (SUS) in the city of Bagé, Rio Grande do Sul, which covers the municipalities of the 7th Regional Health Coordination.

\section{METHODS}

This research was carried out in a cancer treatment clinic in the city of Bagé, Rio Grande do Sul. This treatment unit is a High Complexity Oncology Unit (UNACON), and a reference for the treatment of solid tumors in SUS between the municipalities covered by the 7th Regional Health Coordination: Aceguá, Bagé, Candiota, Dom Pedrito, Hulha Negra and Lavras do Sul.

This study was documentary, retrospective and quantitative in nature and based on the analysis of the medical records of the patients treated at the cancer treatment unit. The data collection period was from December 2010 to June 2017. The collection was performed in the period described because it was the time when the cancer treatment unit began its activities.

The data collection instrument contained closed questions, characterized by a data transcription spreadsheet taken from patient medical records. Data was transferred into charts and tables using Excel. The inclusion criteria were: female patients with breast cancer treated in the SUS health care network, diagnosed in the period described above, receiving treatment or not. The clinical variables studied were: classification and GH, determination of the molecular subtype according to the IHC profile - the criteria for classification are described in Table 1 - ER expression, PR and HER2 oncogene, clinical staging, lymph node involvement, presence or absence of distant metastases, size and compromised breast, in addition to age and color.

The present research was approved by the Research Ethics Committee of the Franciscan University Center (UFN), under Opinion No. 1,977,177. 


\section{RESULTS}

The data obtained from this study illustrated clinical-pathological variables that may influence the prognosis of breast cancer patients. From the analysis of the medical records of patients treated between December 2010 and June 2017, a total of 349 female patients were diagnosed with breast cancer, whose age ranged from 24 to 90 years (mean of 57.4 years ), drawing attention to this diagnosis in young women - in this study, 8.3\% (n = 29) of the patients were under 40 years of age.

The highest frequency of breast cancer occurred in white women (91.7\%; $\mathrm{n}=320$ ), followed by black and brown women (8.3\%; $n=29)$. Regarding the location, $2 \%(n=7)$ of the breast tumors were bilateral, while $46 \%$ ( $n=161$ ) occured in the right breast and $52 \%(\mathrm{n}=181)$, in the left.

Table 2 shows the lymph node involvement, present in $43 \%$ (n $=150)$ of the patients, whereas only $57 \%(n=199)$ of the analyzed cases did not present cancerous cells in lymph nodes. In addition, $6.6 \%(n=23)$ of breast cancer cases had reached the institution with metastases in other organs, such as bones, liver, lungs and brain.

Table 1. Classification criteria of molecular subtypes of breast cancer according to the profile of immunohistochemical markers.

\begin{tabular}{l|c} 
Subtype & Molecular model \\
Luminal A & ER + e/Ou PR +; Ki-67<14\%; HER2 - \\
\hline Luminal B & ER + e/ou PR + ou -; Ki-67 $\geq 14 \% ;$ HER2 + ou - \\
\hline Triple-negative & ER -; PR -; HER2 - \\
\hline HER2 + & ER -; PR -; HER2 + \\
\hline
\end{tabular}

RE: estrogen receptor; RP: progesterone receptor; HER2: human epidermal growth factor receptor 2 .

Table 2. Frequency of variables studied in the breast.

\begin{tabular}{|c|c|c|}
\hline & $\mathbf{n}$ & $\%$ \\
\hline \multicolumn{3}{|l|}{ Size } \\
\hline $\mathrm{T} 1$ & 188 & 53.9 \\
\hline $\mathrm{T} 2$ & 132 & 37.8 \\
\hline T3 & 29 & 8.3 \\
\hline \multicolumn{3}{|c|}{ Lmyph nodes } \\
\hline Yes & 150 & 43.0 \\
\hline No & 199 & 57.0 \\
\hline \multicolumn{3}{|c|}{ Metastases } \\
\hline Yes & 23 & 6.6 \\
\hline No & 326 & 93.4 \\
\hline \multicolumn{3}{|c|}{ Clinical Staging } \\
\hline 1 & 127 & 36.4 \\
\hline II & 113 & 32.4 \\
\hline III & 86 & 24.6 \\
\hline IV & 23 & 6.6 \\
\hline
\end{tabular}

When the size of the tumor nodules were evaluated, it was possible to verify, through Table 2 , that $53.9 \%(\mathrm{n}=188)$ of the tumors were equal to or less than $2 \mathrm{~cm}(\mathrm{~T} 1) ; 37.8 \%(\mathrm{n}=132)$ were nodules between $2 \mathrm{~cm}$ and less than or equal to $5 \mathrm{~cm}$ (T2); and the others, 8.3\% ( $\mathrm{n}=29)$, greater than $5 \mathrm{~cm}$ (T3).

From the previous data, it is possible to establish the clinical staging(CS), starting with stage I, which corresponds to the initial stages of the disease until stage IV, representing the worst prognosis. It was verified that $36.4 \%(n=127)$ of the cases represented CS I, followed by $32.4 \%(n=113)$ for CS II, $24.6 \%$ for CS III $(\mathrm{n}=86)$ and $6.6 \%(\mathrm{n}=23)$ for CS IV (Table 2).

The most frequent types were infiltrating ductal carcinoma (IDC) and invasive lobular carcinoma (ILC), respectively, $79.7 \%$ ( $\mathrm{n}=278)$ and $8.6 \%(\mathrm{n}=30)$. The other histological types, such as papillary, medullary, mucinous, tubular, cribiform, colloid and comedocarcinoma, represented $5.7 \%$ of the sample $(n=20)$.

Regarding the differentiation of tumors according to HS, $8 \%$ $(n=23)$ were stage I, 56.5\% $(n=162)$ stage II and 35.5\% $(n=102)$ stage III. Only carcinomas with ductal foci, except ductal carcinoma in situ, were classified according to the HS, thus totaling 287 patient medical records (Table 3 ).

The results from the IHC markers were evaluated and showed that $6.3 \%(n=22)$ of the analyzed charts had a classification regarding the expression of receptors and the impaired or disabled molecular subtype, since the IHC marker reports from the pathology laboratory did not contain complete information.

Table 3. Frequency of histopathological variables.

\begin{tabular}{|c|c|c|}
\hline & $\mathbf{n}$ & $\%$ \\
\hline \multicolumn{3}{|l|}{ Histological type } \\
\hline IDC & 278 & 79.7 \\
\hline ILC & 30 & 8.6 \\
\hline DLC & 9 & 2.6 \\
\hline DCIS & 9 & 2.6 \\
\hline LCIS & 3 & 0.8 \\
\hline Other & 20 & 5.7 \\
\hline \multicolumn{3}{|l|}{ Histological stage } \\
\hline I & 23 & 8.0 \\
\hline II & 162 & 56.5 \\
\hline III & 102 & 35.5 \\
\hline \multicolumn{3}{|l|}{ Molecular subtype } \\
\hline Luminal A & 65 & 19.8 \\
\hline Luminal B & 212 & 64.8 \\
\hline HER 2 & 18 & 5.5 \\
\hline Triple-negative & 32 & 9.9 \\
\hline
\end{tabular}

IDC: infiltrating ductal carcinoma; ILC: invasive lobular carcinoma; DLC: ducto-lobular carcinoma; DCIS: ductal carcinoma in situ; LCIS: lobular carcinoma in situ; HER 2: epidermal human growth factor receptor-2. 
Thus, it was found that $84.7 \%(\mathrm{n}=277)$ of the patients presented ER and / or PR expression. Overexpression of the HER2 oncogene was present in $12.5 \%(\mathrm{n}=41)$ of the analyzed sample.

By using these markers and the Ki- 67 percentage, it was possible to classify the tumors into four molecular subtypes: Luminal A $(19.8 \%$; $\mathrm{n}=65)$; Luminal B $(64.8 \%$; $\mathrm{n}=212)$ - of these, $10.8 \%$ ( $\mathrm{n}=23)$ presented HER2 overexpression; triple-negative $(9.9 \%$, $\mathrm{n}=32)$; and HER2 (5.5\%; $\mathrm{n}=18)$, as shown in Table 3 .

\section{DISCUSSION}

At present, breast cancer is the second most common cancer in the world, with more than 1.6 million new cases, behind lung cancer, and is considered relatively rare in patients under 40 years of age. However, estimates indicate that approximately $7 \%$ of the cases of this cancer are detected in young women ${ }^{4}$, matching the data obtained in this study. The increase in the number of breast cancer cases in young women may be related to a number of factors, including changes in living standards - particularly urbanization, with the insertion of women into the labor market - pregnancies later in life, changes in eating habits, among others ${ }^{5}$.

Young patients present a differentiated evolution when compared to women over 50 years of age, as cancers diagnosed in more advanced stages have a lower chance of cure, higher mortality rates ${ }^{4}$, and a greater probability of local and distant recurrences. In general, they are triple-negative or HER2-positive type tumors and their treatments are poorly responsive to treatment ${ }^{6}$.

Other features associated with the tumor make the prognosis more unfavorable, such as increased size, lymph node involvement and a high degree of cell differentiation?

Diagnosis of the disease can be done through self-examination of the breasts, clinical examination and mammography $(\mathrm{MM})^{8}$. Although the clinical examination of the breasts does not replace MM, it is fundamental to ensure an early diagnosis of this cancer.

However, it is observed that young women do not present regular visits to the gynecologist as a preventive method, and it is fundamental to stimulate educational actions in order to raise awareness in this population regarding breast cancer screening 5 .

Law 11,664 / 2008, which deals with comprehensive health care for women within the SUS healthcare network, reinforces the need for MM in women aged 40 and over'.

However, our results showed that $8.3 \%$ of the patients were younger than 40 years of age when they were diagnosed with the disease and they were not included in the screening groups. This data draws attention to failures in screening policies and the need to review them in order to include young patients, particularly at-risk patients, in the breast cancer prevention program.

Although the location of the breast is not considered a prognostic factor, our rates corroborate with the study conducted by
Moreno et al. ${ }^{10}$, in which it was shown that $92.6 \%$ of the patients were Caucasian and $53 \%$ were diagnosed in the left breast.

The data regarding the number of involved lymph nodes and distant metastases found in our study were similar to those performed at a hospital in the city of Santa Maria, Rio Grande do Sul, involving 252 breast cancer patients ${ }^{11}$.

However, lymph node involvement in our study, although corresponding to less than half of the total number of patients, was considered high, since this variable is very important in establishing not only the prognosis, but also the therapeutic option and also predicts patient survival ${ }^{12}$, as patients with no metastatic lymph node involvement had overall survival (OS) and diseasefree survival (DFS) above $77 \%$ in 10 years $^{13}$.

It is agreed that tumor size is directly related to the risk of recurrence and the presence of lymph node metastases. Smaller tumors confer better OS and DFS, and can reach up to $88 \%$ survival in 20 years for $\mathrm{T} 1$ patients. In addition, it is also considered a determinant factor in the choice of the type of surgery - mastectomy versus segmentectomy -, since radical surgeries have been gradually less used in favor of the conservative type, due to the early diagnosis of tumors via mammography screening ${ }^{13}$.

Thus, when comparing the size of the tumor nodules, it was observed in our study that most patients were diagnosed with $\mathrm{T} 1$ and a smaller number with T3, while Moraes et al. ${ }^{11}$ showed a higher number of T2 (52,0\%) and T3 (23.8\%)cases, which directly interfer in patients' survival. Rosa and Radünz ${ }^{14}$ also observed a greater predominance of breast cancer diagnosis with sizes ranging from 2 to $5 \mathrm{~cm}$ (T2), demonstrating that, in our study, most patients are diagnosed in the early stages, mainly without metastases in others organs, with a better prognosis and greater chances of cure.

This data ratifies the data obtained for the CS, since the majority of the women (68.8\%) were diagnosed in the early stages, I and II, and the other cases (32.2\%), with advanced disease and metastasis - which, consequently, may make the risk of death, in relation to CS I, 7.18 times higher in patients with CS III and 19.49 times higher in patients with CS IV.

Studies conducted in Brazil describe the predominance of the diagnosis in more advanced stages, particularly in Santa Catarina, where only $18.1 \%$ of the women were diagnosed in the CS $1^{14}$, contrasting once again with the data obtained in this study(36.4\%).

Thus, the predominance of the diagnosis in CSs I and II contradicts the estimates of the Ministry of Health, which indicates the predominance of the advanced stages in Brazil ${ }^{2}$. Therefore, there is a need to increase breast cancer screening in order to reduce diagnostic rates in advanced and metastatic stages. In addition, this difference of indicators between the patients in this study and the national average can possibly be explained by the structuring of a secondary reference network in Mastology - Integrated Oncology and Breast Center - with 
infrastructure and adequate human resources for biopsies of suspicious lesions, including non-palpable lesions, and mammographic screening.

However, developed countries, such as the United States, the United Kingdom and Australia, have already shown a decline in mortality, which is attributed to the increased use of MM and the early treatment of breast cancer. In general, the average survival of breast cancer patients is higher, in five years, in developed countries and lower in developing countries such as Algeria, Brazil, and Eastern Europe. Such differences in survival can be explained by the more advanced stages of diagnosis in developing countries ${ }^{15}$.

In addition to determining tumor size and lymph node involvement, histopathological classification, in relation to type and degree, is also a relevant tool in prognosis, therapeutic choice and predicting patient survival ${ }^{16}$.

Regarding the histological type, most breast cancers are ductal or lobular, and their classification depends on the site where the cancer develops. Lobular tumors are less frequent than ductal tumors; however, approximately $30 \%$ of the cases of lobular carcinoma are bilateral - similar to data obtained in our study, since among the tumors found in both breasts, $28.6 \%$ were lobular. When the tumor is restricted to the duct or lobe it is called in situ, and when it touches adjacent tissues it is called invasive or infiltrating. There are also other histological types, considered less common, but with a better prognosis: medullary, mucinous, tubular and papillary, corresponding to less than $10 \%$ of the cases $^{17}$-similar to what was found in this study.

In developed countries with screening and early diagnosis programs, 20 to $35 \%$ of reported cases of breast cancer are ductal in situ ${ }^{10}$. In the present study, only $2.6 \%$ of the cases presented in situ disease, and although most patients have stages I and II at the time of diagnosis, it is still necessary to improve screening so that the diagnosis can be made even in early stages of the disease, ensuring a greater chance of cure.

The histological evaluation of MM considers the tubule formation, nuclear atypia and mitotic index in order to stage the cancers in three categories: well differentiated (stage I), moderately differentiated (stageII) and poorly differentiated (stage III) ${ }^{17}$. Peiris et al. ${ }^{16}$ and Almeida et al. ${ }^{17}$ found a higher frequency of moderately differentiated tumors, data supported by our study. The MM of tumors is used to guide clinicians in the choice of adjuvant therapies and is used in most decision algorithms of current treatments ${ }^{17}$. In addition, the lower the stage the better the prognosis, since they are less aggressive and, in general, are associated with smaller CS I and II tumors ${ }^{18}$.

The search for IHC marker tests has been increasingly studied in order to predict tumor prognosis, recurrences and other phenotype-tumor variables, and even assist the physician in choosing more specific target therapies ${ }^{19}$. The main predictive factors used in clinical practice are ER, PR and HER $2^{20}$ oncogene.
In isolation, hormone receptors (ER and PR) play an important role in the pathogenesis of breast cancer, since they exert an inhibitory effect on tumor growth. Thus, patients presenting with these receptors have a more favorable prognosis than those who do not ${ }^{18}$.

The IHC markers allow the classification of breast cancers into molecular subtypes according to the degree of expression, such as Luminal A, Luminal B, triple-negative and HER2 overexpression ${ }^{20}$. The Luminal A subtype has low CS, positivity for ER and PR, negative HER2 and a low cell proliferation index. It presents characteristics similar to normal mammary cells, is the most common among breast cancers and has the best prognosis ${ }^{21}$. A study involving 10,159 patients in North America, Europe and Australia showed that this molecular subtype was the most common (71.3\%), followed by triple-negative ( $16 \%)^{22}$, in contrast to the data obtained in our study, which found that this subtype was present in only $19.8 \%$ of the analyzed cases, occupying the second position. These differences can be explained by the ethnic variations of each region, and show the need for more detailed genomic studies ${ }^{23}$.

The Luminal B subtype, which had the highest number of cases (64.8\%), has distinct characteristics that make the prognosis less favorable than Luminal A, because it has a higher rate of cell proliferation, may present HER2 positivity, low expression or absence of ER and PR expression. Thus, the Luminal B subtype is related to a higher risk of recurrence and lower $\mathrm{DFS}^{21}$, which is a disadvantage to the patients in this study, since they represented more than half of the cases analyzed.

When describing the IHC marker profile of 601 patients from a cancer care center in Juiz de Fora, Minas Gerais, Cintra et al. ${ }^{3}$, highlighted a significant number of patients with the Luminal B subtype (41.8\%). However, the authors considered the Ki-67 expression index as high for $\geq 10 \%$ immunopositivit and low for $<10 \%$, based on the criterion adopted at the time of diagnosis.

Therefore, this fact may justify the high percentage of tumors classified as Luminal B found by these authors. Multicentric studies in the five Brazilian regions aimed to identify the frequency of molecular subtypes. The prevalence of each subtype varied as follows: Luminal A, from 24.1 to $30.8 \%$; Luminal B, from 30.8 to 39.5\%; triple-negative, from 14.0 to $20.3 \%$; and HER2 from 6.7 to $13.5 \%$, with Luminal B as the most prevalent subtype ${ }^{24}$.

The differences found in our data with the aforementioned studies can be justified by the fact that Brazil is a country of continental dimensions, with distinct colonization between the five major territorial regions and an intense process of miscegenation, presenting different climatic, urban, nutritional and socioeconomic conditions, factors that influence carcinogenesis and, consequently, cause biological differences regarding breast cancer in the population ${ }^{20}$.

The triple-negative molecular subtype often exhibits higher CS than luminal, is more likely to present metastasis in the lung 
and brain and hormone receptors and HER2 negative expression evaluated by IHC methods ${ }^{25}$. In our study, $9.9 \%$ of the patients had this molecular subtype, corroborating with Delmonico, Alves and Amaral ${ }^{19}$, who highlighted rates of $10-20 \%$ of triple-negative breast cancers occurring in young Afro-descendent women. Despite a predominance of the Caucasian population with breast cancer in this study, we did not correlate race with the triple-negative frequency. The triple-negative subtype presents a resistant phenotype for chemotherapy and does not respond to target drugs or antiestrogenic therapies. For these reasons, it is considered as being the worst prognosis in comparison to the other subtypes ${ }^{19}$.

The absence of hormone receptors, both ER and PR, and HER2 positivity are termed HER2 overexpression. This subtype does not benefit from antiestrogen therapies, however it is responsive to treatment with trastuzumab, a target medication used in patients presenting HER2 protein expression, significantly improving the prognosis of patients ${ }^{26}$. Studies report the occurrence of the HER 2 subtype in approximately $20 \%$ of breast cancer cases $^{12}$, evidencing a considerable difference between our data and those available in the scientific environment. When Borges et al. ${ }^{27}$, checked the HER2 positivity rate and its correlation with the type of biopsy performed, they also observed a number of HER2 positive patients in the literature, demonstrating a significant but slight tendency of HER2 test positivity when the biopsy is performed by core biopsy.

These authors highlighted the need to review the collection, packaging and transport techniques of the sample that may influence the results of tumors that overexpress HER2, thus guaranteeing results that are closer to the literature. Although not evaluated in our study, these factors may have negatively influenced the outcome of HER2 positive cases.
It is worth mentioning that HER2 overexpression, despite not influencing staging, is considered a prognostic factor, since the majority of patients with this characteristic present advanced stages, lymph node involvement, greater probability of distant metastases, higher risk of relapse and lower survival rates when compared to women with negative oncogene ${ }^{18}$.

Thus, knowledge of the clinical and tumor profile of patients with breast cancer is of great relevance to clinical practice, as it helps the physician to determine the prognosis, the DFS and the CS of women with this cancer. It is also important to outline the therapeutic plan and establish the use of more appropriate and individualized therapies.

In our study, we demonstrated that patients treated by the SUS healthcare network in the city of Bagé, Rio Grande do Sul, are diagnosed earlier than other regions of Brazil, evidencing, for the most part, tumors with sizes smaller than $2 \mathrm{~cm}$, without lymph node involvement and early stages. In addition, other prognostic factors, such as the presence of hormonal receptors, subtype Luminal A and B, and a low number of patients with overexpression of the HER2 oncogene, play an important role in patient survival and are associated with a more favorable prognosis.

However, it is still necessary to adopt measures that guarantee the diagnosis in pre-invasive phases, like in developed countries, where the chances of cure are higher and patients have a better quality of life.

\section{ACKNOWLEDGEMENTS}

We would like to thank the administrator of the Bagé Clinic, Marilene Oliveira Nunes, for making it possible to carry out the research in this institution.

\section{REFERENCES}

1. Cesar PGC, Fonseca FLA, Gehrke FS, Alves BCA, Kuniyoshi RK, Del Giglio A. Utilização de plataforma gênica no prognóstico. Arq Bras Ciên Saúde. 2012;37(3):154-61.

2. Brasil. Ministério da Saúde. Instituto Nacional do Câncer. Estimativas - 2018: Incidência de Câncer no Brasil [Internet]. Brasil: Ministério da Saúde; 2018 [acessado em16 out. 2018]. Disponível em: http://www.inca.gov.br/estimativa/2018/estimativa-2018.pdf

3. Cintra JRD, Teixeira MTB, Diniz RW, Gonçalves Junior H, Florentino TM, Freitas GF, et al. Perfil imuno-histoquímico e variáveis clinicopatológicas no câncer de. Rev Assoc Méd Bras. 2012;58(2):178-87. http://dx.doi.org/10.1590/S010442302012000200013

4. Lima ALP, Rolim NCOP, Gama MEA, Pestana AL, Silva EL, Cunha CLF. Rastreamento oportunístico do câncer de mama entre mulheres jovens no estado do Maranhão, Brasil. Cad Saúde Pública. 2011;27(7):1433-39. http://dx.doi.org/10.1590/ S0102-311X2011000700018
5. Correia SB, Souza FB, Abrahão DPS, Abdalla DR, Carvalho EEV, Abdalla JK. Prevalência de pacientes jovens diagnosticadas com câncer de mama e em tratamento na cidade de Uberaba MG. J Contextual Behav Sci. 2015;1(1):28-32.

6. Paluch-ShimonS, PaganiO, PartridgeAH,AbulkhairO, Cardoso MJ, Dent RA, et al. ESO-ESMO 3rd international consensus guidelines for breast cancer in. Breast. 2017;35:203-17. https:// doi.org/10.1016/j.breast.2017.07.017

7. Sharma D, Singh G. Breast cancer in young women: A retrospective study from tertiary care. South Asian J Cancer. 2017;6(2):51-3. https://dx.doi.org/10.4103\%2F2278330X.208859

8. Matos JC, Pelloso SM, Carvalho MDB. Fatores associados à realização da prevenção secundária do câncer de mama no Município de Maringá, Paraná, Brasil. Cad Saúde Pública. 2011;27(5):888-98. http://dx.doi.org/10.1590/S0102311X2011000500007 
9. Brasil. Ministério da Saúde. Lei no $11.664 / 2008$. Dispõe sobre a efetivação de ações de saúde que assegurem a prevenção, a detecção, o tratamento e o seguimento dos cânceres do colo uterino e de mama, no âmbito do Sistema Único de Saúde SUS [Internet]. Brasil: Ministério da Saúde; 2008 [acessado em set. 2017]. Disponível em: http://www.planalto.gov.br/ ccivil_03/_Ato2007-2010/2008/Lei/L11664.htm

10. Moreno M, Biazi CL, Proner C. Câncer de mama na região oeste de Santa Catarina. Rev Bras Mastologia. 2012;22(4):111-6.

11. Moraes AB, Zanini RR, Turchiello MS, Riboldi J, Medeiros LR. Estudo da sobrevida de pacientes. Cad Saúde Pública. 2006;22(10):2219-28. http://dx.doi.org/10.1590/S0102311X2006001000028

12. Gonçalves LLC, Santos SB, Marinho EC, Almeida AM, Santos AHS, Barros ÂMMS, et al. Câncer de mama feminino: aspectos clínicos e patológicos dos casos cadastrados de 2005 a 2008 num serviço público de oncologia de Sergipe. Rev Bras Saúde Materno Infantil. 2012;12(1):47-8. http://dx.doi.org/10.1590/ S1519-38292012000100005

13. Abreu E, Koifman S. Fatores prognósticos no câncer de mama feminino. Rev Bras Cancerologia. 2002;48(1):113-31.

14. Rosa LM, Radünz V. Taxa de sobrevida na mulher com câncer de mama: estudo de revisão. Texto Contexto Enferm. 2012;21(4):980-9. http://dx.doi.org/10.1590/S010407072012000400031

15. Soares PBM, Quirino Filho S, Souza WP, Gonçalves RCR, Martelli DRB, Silveira MF, et al. Características das mulheres com câncer de mama assistidas em serviços de referência do Norte de Minas Gerais. Rev Bras Epidemiol. 2012;15(3):595-604. http://dx.doi.org/10.1590/S1415-790X2012000300013

16. Peiris H, Mudduwa L, Thalagala N, Jayatialake K. The value of Nottingham grade in breast cancer re-visited in the Sri Lankan setting. Malays J Pathol. 2017;39(2):141-8.

17. Almeida AMPT, Marquini HR, Leite RM, Nai GA. Prevalência de câncer de mama e associação com seus fatores prognósticos e preditivos. Colloquium Vitae. 2012;4(1):27-37.

18. Stafin I, Caponi LGF, Torres TP, Araujo JN, Guedes VR. Fatores prognósticos no câncer de mama. HU Rev. 2014;38(3-4):193-201.
19. Delmonico L, Alves G, Amaral LFP. A biologia do câncer de mama e testes moleculares de prognóstico. Rev Hupe. 2015;14(Supl. 1):59-65. http://doi.org/10.12957/ rhupe.2015.17928

20. Carmo PO, Leite ICG, Guerra MR. Sobrevida de mulheres com câncer de mama subtipo luminal assistidas em Juiz de Fora, Minas Gerais, Brasil. Rev Bras Mastologia. 2016;26(3):118-25. http://doi.org/10.5327/Z201600030007RBM

21. Cirqueira MB, Moreira MAR, Soares LR, Freitas-Jr R. Subtipos moleculares do câncer de mama. Femina. 2011;39(10):499-503.

22. Blows FM, Driver KE, Schmidt MK, Broeks A, Leeuwen FE, Wesseling J, et al. Subtyping of Breast Cancer by Immunohistochemistry to Investigate a Relationship between Subtype and Short and Long Term Survival: A Collaborative Analysis of Data for 10,159 Cases from 12 Studies. Plos Med. 2010;7(5):1-12. https://doi.org/10.1371/journal.pmed.1000279

23. Barreto-Neto NJS, Pinheiro AB, Oliveira JF, Crusoé NSDR, Bertrand SAB, Machado MCM, et al. Perfil epidemiológico dos subtipos moleculares de carcinoma ductal da mama em população de pacientes em Salvador, Bahia. Rev Bras Mastologia. 2014;24(4):98-102. http://doi.org/10.5327/ Z201400040002RBM

24. Carvalho FM, Bacchi LM, Pincerato KM, Van de Rijn M, Bacchi CE. Geographic differences in the distribution of molecular subtypes of breast cancer in Brazil. BMC Womens Health. 2014;14(102):102. https://doi.org/10.1186/1472-6874-14-102

25. Casadiego AKR, Bianchi GI. Carcinoma de la mama triple negativo aspectos morfológicos y expresión de CK 5/6. Rev Venez Oncol. 2011;23(1):2-13.

26. Stival RSM, Prestes ALO, Mansani F. Câncer de mama em mulheres jovens: uma análise do estadiamento clínico inicial e dos subtipos moleculares dos tumores. Rev Bras Mastologia. 2014;24(1):17-22. http://doi.org/10.5327/Z201400010004RBM

27. Borges TO, Vogt MFB, Salum FCA, Calvano Filho CMC, Wanderley MS, Zaconeta ACM, et al. Avaliação da taxa de positividade do receptor HER2 e da influência de três tipos de biópsia mamária no resultado imunohistoquímico em mulheres com câncer de mama invasivo no Hospital Universitário de Brasília. Rev Bras Mastologia. 2012;22(3):83-9. 